\title{
1
}

\section{Progress and propaganda in Timor-Leste: Visions of the future in comparative historical perspective}

\section{Douglas Kammen}

It has now been just over a decade since revenue from Timor-Leste's offshore oil and gas fields began to accrue in the country's Petroleum Fund, making possible vast increases in the size of the annual state budget and public spending. This set the stage for the Government of Timor-Leste to formulate plans for a number of megaprojects intended to fuel rapid economic development. Politicians and planners envisioned a petroleum corridor on the south coast: a pipeline and divided highway would connect a supply base, a petrochemical refinery, a liquefied natural gas plant, and entirely new planned cities. In Dili, plans were drawn up for a glittering new port facility in Tibar and a complete overhaul of the national airport, including a runway spanning the sandy Comoro River. Down the coast, new legislation designated Oecusse to be a Special Zone for Social Market Economy, where a proposed US\$4.1 billion in combined state and private investment promised to create a shining new city with high-tech manufacturing, a major port facility and a world-class university. Public debate in Timor-Leste over these major infrastructure projects quickly became polarised, with critics charging that the allocation of funds for these projects was naïve, reckless and irrational, while government officials 
countered with accusations that critics were misinformed about project aims, alarmist about outcomes and unsympathetic to the legitimate desires of the Timorese people.

It is perhaps useful to recall that visions of future prosperity are by no means new in Timor. In the sixteenth and seventeenth centuries, representatives of the Portuguese crown speculated about the presence of vast mineral wealth in Timor. In the mid-nineteenth century, Portuguese governors discussed the possibility of replicating the cultivation system in Dutch-held Java to produce an agricultural bounty. But neither minerals nor agriculture ever produced a surplus for the state, and the colony entered the twentieth century little changed from the 'most miserable place' encountered by Alfred Russel Wallace (1869: 197) in 1861 and the 'abominable town' Joseph Conrad (2004: 57) visited two decades later.

This chapter examines visions of Timor-Leste's future that emerged following three critical junctures in the territory's modern history - the 1910 republican revolution in Lisbon, the 1975 Indonesian invasion and subsequent annexation of Portuguese Timor, and the 1999 referendum on independence. Following each of these upheavals, external powers formulated and propagated ideas about the fundamental transformation of Timor and Timorese peoples. Comparative sketches of these visions and the means proposed for their achievement may provide a helpful framework for thinking about contemporary dreams of the future in Timor-Leste.

\section{The fountain of life}

The 1910 republican revolution in Portugal marked a critical juncture in the history of the overseas empire. The new Republican Government promised administrative reforms that would drag Portugal and its empire into the twentieth century. In the colonies, however, the message promoted by Portuguese officials, many of whom were staunch monarchists, was one of benevolent metropolitan tutelage and colonial loyalty. This attitude is nicely illustrated by the first public speech by beleaguered Governor Soveral Martins in Dili on 5 November 1910:

A telegraph brought us news of the revolt that gave Portugal a new regime, satisfying the ideals of its people and its future by opening a new era of happiness and progress for all. Loyal daughter, the colony of Timor could not but follow, with loving enthusiasm, the mother country, embracing the new ideas with faith in the future and enduring belief in a greater Portugal. (Quoted in Oliveira 2004: 43) 
This was wishful thinking, for a year later the imminent threat posed by republicanism to indigenous rulers (both regulos and village-level chefes de suco) and a sharp increase in the head tax contributed to a major armed uprising in Manufahi district that was taken up in a number of other regions in the colony.

If the republican revolution of 1910 marked a key juncture, the content of the new Portuguese vision of progress only took shape gradually over the following two decades. It was driven by the interplay of two related processes, the origins of which were fundamentally external to Timor. The first of these was the adoption of emerging international techniques of governmentality. In 1905, Portugal promoted new international standards for the modern census in its colonial possessions. This quickly - and for the first time - led to the collection of systematic population data and facilitated far more efficient taxation. The second dynamic involved passage of a series of juridical codes and legislative decrees regarding the place of the indigenous colonial peoples within the Portuguese nation. Borrowing practices most fully developed in the Netherlands Indies and French colonies in Africa, the Portuguese state began to codify customary practices into a separate legal system applicable to the indigenous population (Clarence-Smith 1985: 138; Newitt 1995: 449). These initiatives marked the transition from the old 'monarchical' model, in which Timorese villagers were viewed as subjects of particular kingdoms-cum-administrative units, to a new imperial model in which indigeneity implied non-civilised status.

Racially based colonial legislation was counterbalanced by new promises of inclusion. Laws on assimilation were passed in the African colonies in the late 1910s and replicated in Timor via Decree-Law 7/151 of 1920. This opened up the possibility for cultural advancement - from non-civilised to civilised status - for those who could demonstrate that they were Christian, spoke Portuguese, were monogamous and dressed in European fashion. Colony-specific legislation was superseded in 1930 by promulgation of an empire-wide organic statute. Article 2 of this statute stated:

It belongs to the organic character of the Portuguese nation to fulfil its historical mission: to possess and colonise overseas territories and to civilise the indigenous population living in them, thus at the same time exerting the moral influence to which it is committed by the Padroado over the Orient. (Ferreira 1964: 54) 
The new slogan was 'One state, one race, one faith, and one civilisation'. This was, in short, a radically new vision of a future in which, at least in theory, Timorese could and would become Portuguese.

The reality, however, was that the requirements for assimilation were so stringent, and bureaucratic intransigence so strong, that assimilated status lay out of reach for the vast majority of the indigenous population. In Angola and Mozambique, less than 1 per cent of the population achieved this status in the 1930s. The number of assimilados in Portuguese Timor was not reported in the colonial censuses in the 1930s, but we can be certain that only a tiny number of individuals successfully achieved this status. One reason, no doubt, was that the arrival of significant numbers of deportees (political deportados as well as social degredados) had a profound impact on status consciousness and the hardening of a 'colour' bar in the colony. In 1951, the only year for which figures are available for Portuguese Timor (Felgas 1956: 329), there were only 1,541 Timorese who had formally been granted assimilado status. ${ }^{1}$

While Prime Minister António Salazar's Estado Novo (New State) promoted the idea of Portugal's historic mission to civilise colonial subjects and promised that these subjects (or, more accurately, their descendants) could become full members of the Portuguese nation, few officials believed that this would in fact ever occur. This scepticism was stated most directly by Colonial Minister Armindo Monteiro in 1935:

We do not believe that a rapid passage from their African superstitions to our civilization is possible. For us to have arrived where we are presently, hundreds of generations before us fought, suffered and learned, minute by minute, the intimate secrets in the fountain of life. It is impossible for them [African and other colonial subjects] to traverse this distance of centuries in a single jump. (Quoted in Isaacman and Isaacman 1983: 40)

In official circles in the Ministry of Overseas Affairs and in Portuguese Timor, the view was that the indigenous population was indolent accepting of bare subsistence livelihoods - and economically wasteful, squandering livestock and other hard-earned resources for ceremonial rather than economically 'rational' purposes. These officials thus concluded

1 In response to the colonial wars in Africa, the legal statute specifying the categories 'civilised' and 'non-civilised' was abolished in 1961 and all colonial subjects were henceforth declared Portuguese citizens (Ferreira 1964: 37). 
that the solution lay in forcing Timorese peoples to engage in productive labour, which would not only monetise the economy and benefit state coffers, but also transform the indigenous population.

The three strands of the Portuguese vision - Timorese loyalty, civilisational advancement and the need for the disciplinary power of labour - were put on display in the colonial exposition held in the town of Liquiçá in 1937. The exposition was accompanied by an extensive photographic effort between 1937 and 1940 to document the indigenous population and the civilising mission of the colonial state (Salema 2003). These photographs are divided into three sections. The first section, titled 'Types of Secondary Characteristics and Languages' (Tipos característicos segundo as línguas), includes hundreds of photographs of bare-chested couples - some old, some young - as well as images of loyal traditional rulers, individuals in traditional dress and Catholicised women. The second section, called 'Forms of Work' (Formas de Trabalho), is divided into subsections that cover industry, commerce, rural arts, indigenous crafts and musical instruments. A final section, titled 'Civilising and Colonising Actions' (Acçâo Civilisadora e Colonisadora), documents public works projects, sanitation, schools, missionary activities and administration.

The irony, of course, is that in their two centuries in Timor, the Portuguese themselves had demonstrated little in the way of initiative, discipline or labour. In the 1930s, roads beyond Dili were still dirt tracks, buildings were dilapidated and there was virtually no manufacturing. The official promise of progress and the 'vision' of future civilisation and citizenship was, in short, a chimera. Furthermore, it was a product of the African colonies that, once imported into Portuguese Timor, became more fantasy than reality. Nonetheless, insofar as the vision was premised on a comparison of the Portuguese and the indigenous subjects, it included the Timorese people as not only objects, but also willing agents of their own subjugation.

\section{Mother's lap}

General Suharto's New Order regime justified the invasion of Portuguese Timor in December 1975 on the grounds that it was acting to prevent the emergence of a communist foothold in island Southeast Asia and end what they presented as a 'civil war' between the nascent East Timorese political parties. At a deeper historical level, Indonesia rationalised the 
invasion and integration of East Timor in terms of two assumptions about the past. The first of these is the wholly anachronistic notion that East Timor was part of great pre-colonial empires, to which Indonesian ideologues traced the country's political ancestry. A book produced by the Department of Foreign Affairs (1977: 12), for example, claimed: 'Prior to the arrival of the colonial powers, Timor had been part of the Sriwijaya and Mojopahit Empires, which successfully dominated much of Southeast Asia for nearly one thousand years'. In this view, European colonialism had separated the East Timorese people (conceived in the singular!) from 'mother' Indonesia (also anachronistically conceived as pre-existing). The introduction to a 1976 volume on the 'integration' of East Timor into the Republic of Indonesia could thus explain:

Although the actual physical struggle only lasted for two years, the aspiration for 'integration with Indonesia' that motivated that struggle had, in truth, existed and remained alive in the hearts of the East Timorese people for decades, even centuries. It was already there before the people of East Timor were separated from the big family of the Indonesian people by the colonial powers. Indeed, the aspiration for 'integration with Indonesia' repeatedly motivated rebellions by the East Timorese people against the colonial government in 19 [sic], 1945-1949, and 1959. (Soekanto 1976: preface)

The second feature of Indonesian thinking was that over the course of four centuries, Portugal had failed to develop the territory of East Timor and its people. Drawing on imagery prominent in early Indonesian nationalist discourse, Indonesian officials depicted the period of Portuguese rule as an age of "darkness" and the Indonesian period as an age of "light" (Mubyarto et al. 1991: 59). To support this charge, Indonesian statements and publications drew on a wide array of statistical data that the Salazar-Caetano dictatorship had made pains to present to the world in English. This line of thinking is nicely captured in a 1984 article in the Jakarta press:

The Indonesian government placed great emphasis on Portuguese neglect of its colony, citing figures on how few roads had been paved, limited access to education, and the lack of basic health care outside of Dili. After 400 years of colonial rule, Portugal had only established 70 primary schools; after 8 years Indonesia had established 436 primary schools. (Achiruddin 1984) 
Based on these twin assumptions about the past, Indonesian propaganda presented integration as a family reunion. In his 1976 independence day address, president Suharto directly addressed the East Timorese people, stating, 'We view you as siblings now returning to the big family of the Indonesian nation'. Government publications repeatedly celebrated East Timor's 'return to the lap of mother Indonesia' (Soekanto 1976). Certain of the righteousness of their cause, Indonesian officials believed the invasion of Portuguese Timor would be easy, integration of the territory into the Republic of Indonesia uncontested, and the benefits of returning to 'mother Indonesia' welcomed by the population.

If in 1976 Indonesian officials could present choreographed voting as selfdetermination and waving crowds as evidence of popular approval, then what vision did Indonesian officials have of the future of the new province? Certainly not the ensuing two years of frontal warfare, the devastating loss of life from hunger and disease in 'relocation camps', or the heroic survival of Fretilin's armed resistance. Rather, the official Indonesian vision of East Timor's future replicated New Order propaganda at home: technical know-how and political order would lead to development (pembangunan), which could be measured in quantifiable units of roads and bridges, irrigation canals and rice production, schools and clinics, and even the ever-growing number of letters posted and increasing attendance at the movie theatre. On 16 October 1984, the Jakarta Post reflected official views of the province's tremendous potential:

Vast resources remain untapped in E. Timor. If all funds and forces in East Timor are mobilised by dint of advanced technology, the province is bound to become the richest in the country.

This vision is depicted most clearly in the volumes published on a nearannual basis by the Indonesian Government. These show, in sequential order, images of the backward state of the territory resulting from four centuries of Portuguese rule, development projects funded by Jakarta and officials in modern uniforms happily encouraging development. Most importantly, the movement from backwardness to modernity is captured in an array of bar charts, pie charts, graphs and tables - proof of good intentions and the promise of future prosperity.

Most international observers rightly dismissed the official Indonesian claims about physical and social development in the territory as propaganda intended to gloss over the terrible abuses of fundamental rights perpetrated in the territory. The most revealing critique of official reporting came 
not from abroad, but rather from a research team, headed by Professor Mubyarto, from the Gadjah Mada University Research Centre for Village and Regional Development. The research was commissioned by the Bank of Indonesia to assess why the East Timorese people were 'uncooperative, apathetic and constantly suspicious' (Mubyarto et al. 1991: viii). The researchers visited the territory in 1981, the year of the massive 'fence of legs' operation against the armed resistance, with a second visit in 1989, just as the province was being 'opened' to Indonesian as well as foreign visitors. The final report includes chapters on 'Village Life and Economy', 'Social, Political and Religious Systems', 'Problems of Village Development', and a concluding chapter entitled 'Towards Peace and Prosperity'. The report concluded:

[while] the integration of East Timor into Indonesia has brought physical progress to the island, it has not yet been able to eliminate social, economic and political problems resulting from an integration process which has cost too many human lives. (ibid.: 4 )

The authors identified two fundamental reasons for East Timorese alienation: first, military rule over the territory; and second, the exclusion of key groups, including 'traditional community leaders', educated youth and the Catholic Church, from meaningful participation in social and political life. Together, military rule and political exclusion resulted in 'trauma' and 'culture shock'. The report, in short, laid bare the hollowness of Indonesian propaganda about progress.

The English-language version of the Gadjah Mada report was made public in December 1991, a mere month after the tragic Santa Cruz massacre, in which more than 250 young Timorese were massacred during a peaceful funeral procession. This marked a turning point not only in the resistance, but also in how Indonesian officials discussed the East Timor problem, with increasingly open laments about how 'ungrateful' the East Timorese were for the development that Indonesia had brought.

The answer to the East Timor problem, of course, was more propaganda. While the Indonesian military scrambled to respond to the Santa Cruz massacre, still others sought to shore up the vision of a happy and prosperous future in Indonesia's 27th province. Although produced before Santa Cruz, one of the most telling propaganda efforts was the 1990 film Langit Kembali Biru, about two young lovers wrenched apart by the political conflict of 1975. Manuel is a Fretilin supporter who becomes a guerrilla fighter in the jungle, while his girlfriend Ana (played 
by Governor Carrascaláo's daughter Sonia) is from a family that supported integration with Indonesia. In the end, of course, love wins out: Manuel comes over to the pro-integration side and marries Ana to live happily ever after in the bounty bestowed by Indonesia's Father of Development.

\section{A world of norms}

In some respects, the United Nations' vision for East Timor was set from the time of the 5 May 1999 agreement to hold a referendum on the future of the territory. This did not mean that the long-suffering people of East Timor (which later became Timor-Leste) would immediately join the ranks of independent nation-states (the personal views of UN officials notwithstanding), but rather that basic human rights would be protected and the right to self-determination upheld. The violence perpetrated by the Indonesian military and the pro-Jakarta militias in the lead-up to the referendum served to harden this basic perspective on the $\mathrm{UN}$ role. When the results of the referendum were announced on 4 September 1999, the Indonesian military and its proxies engaged in a final spree of violence, destroying infrastructure and forcing hundreds of thousands of East Timorese into Indonesian West Timor, presumably to demonstrate that the population was 'voting with their feet' in favour of Indonesia.

It was under these circumstances that the UN scrambled to assemble an international peacekeeping force, eventually led by Australia, and, with a decision by the Indonesian Parliament to formally relinquish the territory, to establish the United Nations Transitional Administration in East Timor (UNTAET). The UNTAET mandate was clear: 'to provide security and maintain law and order throughout the territory', 'to establish an effective administration' leading to independence, and 'to establish the conditions for sustainable development' (UNSC 1999: 2-3).

Over the next decade there was a huge outpouring of writing on TimorLeste, of which more than half focused squarely on the UN. The two themes that dominate this literature are peace-building and state-building, often conflated. Many of the most reflective authors exhibit a sense of unease, as if something that doesn't quite fit - or perhaps fits too well (Chopra 2002; Hasegawa 2013). For this reason, it is perhaps useful to step back from these concerns, which were more about the UN itself than Timor-Leste, by considering the distinction between state-building, which involves extending the geographic reach of the state and the strength of 
its institutions, and regime-building, which involves setting the rules within which political activity is conducted and teaching these rules to the population at large. Viewed in these terms, we can better untangle the mandates of the various UN missions that operated in Timor-Leste between 1999 and 2010, as well as how the highest-ranking UN officials viewed their task and the future of the territory.

The UNTAET mission, which was in charge of the political transition from 1999 until the restoration of independence in May 2002, quickly came face to face with the problem of reconciling the aims set out in its mandate. UNTAET, Anthony Goldstone (2004: 85) writes, placed 'a premium on achieving short-term humanitarian and administrative goals at the expense of longer-term capacity- and institution-building goals'. Alongside this, the United Nations Development Programme (UNDP) and the World Bank were both intent on introducing a variety of neoliberal norms and practices. The precise details of these arrangements are beyond the concern of this article. For present purposes, the key point is that greater stress was placed on establishing the rules of the game than on building institutions that would support the new state when independence was restored in May 2002.

The United Nations Mission of Support in East Timor (UNMISET), mandated to provide assistance to the new government of Timor-Leste, was in place from 2002 until 2005. UNMISET retained responsibility for security for several years, leading a number of commentators to question just how sovereign the new state of Timor-Leste really was. Beyond this technical consideration, and clearly with an eye to allowing the new government to stand on its own two feet, UNMISET adopted a largely consensual approach, seeking to provide assistance without dictating the formation of institutions or their mandates. Meanwhile, UN emphasis shifted even more strongly in the direction of promoting international norms. This meant encouraging the Government of Timor-Leste to become signatory to a variety of human rights instruments, encouraging Timor-Leste to meet standards for female political representation, and assisting Timor-Leste in joining international associations. In short, the UN vision was one in which Timor-Leste was entering a world of rules.

The 2006 crisis may have shaken international faith in the work of the previous six years, but it also resulted in a rapid decision to deploy yet another mission, the United Nations Integrated Mission in East Timor (UNMIT), which, in the context of the political conflict, publicly declared 
its neutrality while clearly siding with Xanana Gusmão and the emerging coalition of parties that came to power in 2007 as the Parliamentary Majority Alliance. From the time of the crisis until the mission's end in 2012, the emphasis shifted back to peacekeeping, with support for statebuilding largely hived off to UNDP and the World Bank.

What, then, was the UN vision of Timor-Leste's future? The short answer to this question is that the $\mathrm{UN}$ and its international development partners were eager to usher Timor-Leste into a world of international norms, including a host of human rights instruments, procedural democracy and a market economy with a limited role for the state. A more detailed answer emerges when we consider the three-volume set of photographs released by UNMIT (2012) at the end of the mission. Securing the Future highlights the role of UN peacekeepers and police in maintaining security and training the new East Timorese security forces. A second volume, entitled Building on Stability, highlights the role of the UN in statebuilding, with photographs showing national elections, the installation of elected officials, judges and the Dili District Court, and meetings of the East Timor Development Partners. The third volume, Capturing the Moment, contains stereotypical photographs of beautiful scenery, smiling children, agriculture and fishing, traditional crafts and plenty of elders.

The effect of these volumes was to announce that - under the guidance of the UN, its missions and international development partners a democratically elected government, a competent civil service and committed security forces would govern 'traditional' Timorese in rural settings, and urban youth receiving modern education would still proudly dress in colourful double-woven cloth for special occasions. The UN vision was, to borrow a phrase from Rudolf Mrazek (2002), one of itself as 'engineers of happy land'.

\section{Conclusion}

This brief history of the future in Timor-Leste has several useful implications for how we think about the present schemes being peddled for a petroleum corridor, planned cities, a special economic zone with high-tech manufacturing, and prestige projects planned for Dili. 
First is the matter of state power. The three cases described here all involve visions formulated by foreign powers. By contrast, the current visions are, for the first time in Timor's history, being formulated by East Timorese themselves. However, I think it is misleading to view the 1999-2002 period as marking a complete rupture and to focus on the 'indigenous' sources of these visions. Rather, we should see the administrations of Xanana Gusmão (2007-2015) and his handpicked successor Rui Maria de Araújo (2015-2017) first and foremost as holders of state power, and as such we should ask in which ways they may be replicating perspectives and assumptions characteristic of prior regimes.

The second point concerns the core aspects of the visions promoted by each state. From the time of the 1910 republican revolution, the centrepiece of the Portuguese vision was one of civilisational progress made possible through labour. Following the 1975 invasion, the core of the Indonesian vision was one of quantifiable development achieved thanks to the know-how of the 'wise parent'. After the 1999 referendum, the core vision of the UN missions was one of a new member state adopting and adhering to international best practices and norms, while any deviation would risk damnation in the ranks of failed states. The longterm vision peddled by the current government of Timor-Leste is most closely akin to the Indonesian fetishisation of development, though with one critical difference: whereas the Indonesian vision of physical and economic development always subordinated Timor to a larger, more advanced 'centre', the current vision involves leapfrogging, in the short span of two decades, from a subsistence economy to one characterised by high-tech production and advanced services. Yet the current schemes say very little about labour, know-how or comparative lessons. Instead, current visions of progress are premised solely on capital derived from finite oil and gas reserves.

Third, what place was there for Timorese in each of these visions? In the 1920s and '30s, the indigenous were not simply objects of colonial rule; instead, like Shakespeare's Caliban, they were to be subjects of their own subjugation. The colonial regime would provide the structures for longterm cultural assimilation, but it was up to individuals to make themselves something other than indigenas. During the Indonesian occupation, by contrast, East Timorese were to be the passive recipients of development, but at least they were acknowledged as part of the equation. For all its good intentions, the UN vision of international norms, democratic institutions and security is a vision of increasingly pronounced differentiation between 
elected officials and those recruited to work in the modern state, on the one hand, and grateful peasants living traditional lives, on the other. When we turn to visual representations of the petroleum corridor, the Special Zone for Social Market Economy (ZEESM [Zonas Especiais de Economia Social de Mercado de Timor-Leste]) in Oecusse, and other proposed megaprojects, however, one cannot help but notice that Timorese are almost entirely absent. These are plans without people - or at least without recognisably East Timorese people.

\section{References}

Achiruddin (1984) 'Bagaimana Timor Timur pada Saat Tinggal Landas?' [How is East Timor at the time of take-off?], Merdeka, 4 June.

Chopra, J. (2002) 'Building state failure in East Timor', Development and Change, vol. 33, no. 5, pp. 979-1000. doi.org/10.1111/1467-7660.t01-1-00257.

Clarence-Smith, W. G. (1985) The third Portuguese empire, 1825-1975: A study in economic imperialism, Manchester: Manchester University Press.

Conrad, J. (2004 [1915]) Victory: An island tale, Oxford and New York: Oxford University Press.

Department of Foreign Affairs (Republic of Indonesia) (1977) Decolonization in East Timor, Jakarta: Department of Information, Republic of Indonesia.

Felgas, H. (1956) Timor Português, Lisbon: Agência Geral do Ultramar.

Ferreira, E. da Sousa (1964) Portuguese colonialism in Africa: The end of an era, Paris: The UNESCO Press.

Goldstone, A. (2004) 'UNTAET with hindsight: The peculiarities of politics in an incomplete state', Global Governance, vol. 10, pp. 83-98.

Hasegawa, S. (2013) Primordial leadership: Peacebuilding and national ownership in Timor-Leste, Tokyo: United Nations University Press.

Isaacman, A. and Isaacman, B. (1983) Mozambique: From colonialism to revolution, 1900-1982, Boulder: Westview Press.

Mrazek, R. (2002) Engineers of happy land: Technology and nationalism in a colony, Princeton and Oxford: Princeton University Press. 
Mubyarto, L. S., Hudiyanto, E. D., Setiawati, I. and Mawarni, A. (1991) East Timor: The impact of integration, Australia: Gadjah Mada University Research Centre for Village and Regional Development and Indonesian Resources and Information Program.

Newitt, M. (1995) A history of Mozambique, Bloomington and Indianapolis: Indiana University Press.

Oliveira, L. de (2004) Timor na história de Portugal [Timor in the History of Portugal], vol. 3, Lisbon: Agência Geral do Ultramar.

Salema, I. (2003) 'Álbum de Timor colonial dos annos 30 doado a Xanana Gusmão' [Colonial Timor's album of the 30s donated to Xanana Gusmão], Publico, 5 March.

Soekanto (ed.) (1976) Integrasi: Kebulatan Tekad Rakyat Timor Timur [Integration: Determination of the people of East Timor], Jakarta: Yayasan Parikesit.

UNMIT (United Nations Mission in East Timor) (2012) Building on stability, securing the future, and capturing the momentum, 3 vols, UNMIT.

UNSC (United Nations Security Council) (1999) Resolution 1272, 25 October 1999. Available at: dag.un.org/bitstream/handle/11176/36759/S_RES_1272 \%281999\%29-EN.pdf.

Wallace, A.R. (1869) The Malay Archipelago: The land of the orang-utan, and the bird of paradise, New York: Harper and Brothers Publisher. 
This text is taken from The Promise of Prosperity: Visions of the Future in Timor-Leste, edited by Judith Bovensiepen, published 2018 by ANU Press, The Australian National University, Canberra, Australia.

doi.org/10.22459/PP.2018.01 